\title{
Правові аспекти хірургічної корекціі статевої належності в Україні
}

А. М. Біляков, Н. М. Ергард, П. Ф. Музиченко

Національний медичний університет імені О. О. Богомольця, м. Київ

\section{Legislative aspects of surgical correction of gender in Ukraine}

\author{
A. M. Bilyakov, N. M. Ergard, P. F. Muzychenko
}

Bogomolets National Medical University, Kyiv

\begin{abstract}
Реферат
Мета. Аналіз сучасного стану правового забезпечення хірургічної корекції статевої належності в Україні.

Матеріали і методи. Проаналізовано Постанову Верховної Ради України «Про затвердження положень про паспорт громадянина України та про паспорт громадянина України для виїзду за кордон», статті 42, 51 Основ законодавства України про охорону здоров'я, Наказ Міністерства охорони здоров'я України від 3 лютого 2011 р. №60 «Про удосконалення надання медичної допомоги особам, які потребують зміни (корекції) статевої належності» та Наказ Міністерства охорони здоров’я України від 5 жовтня 2016 р. №1041 «Про встановлення медико-біологічних та соціально-психологічних показань для зміни (корекції) статевої належності та затвердження форми первинної облікової документації й інструкції щодо ії заповнення» (далі - Наказ МОЗ України від 5 жовтня 2016 р. №1041).

Результати. Досі залишається актуальним питання правового супроводу корекції (зміни) статевої належності в Україні і немає єдиного принципу дотримання певного алгоритму дій лікаря-хірурга під час лікування хірургічних хворих, хоча відповідно до Наказу МОЗ України від 5 жовтня 2016 р. №1041 процедура отримання дозволу для корекції статевої належності стала дещо спрощеною. Однак положення цього наказу й дотепер викликають дискусії і можуть мати наслідки правового характеру для лікаря-хірурга, який виконує свої службові обов'язки.

Висновки. Діяльність МОЗ України, спрямована на приведення у відповідність до світових стандартів правової регламентації зміни (корекції) статевої належності, потребує не лише державної підтримки та запровадження відповідних програм, а й подальшої законодавчої ініціативи з метою закріплення даних положень на державному рівні щодо осіб, стать яких є невизначеною.

ключові слова: хірургія; нормативно-правова база; транссексуал; гендерна політика.

Abstract

Oblective. Analysis of modern state of legislative provision of surgical correction of the gender determining in Ukraine.

Materials and methods. About establishment of "Provisions about passport of citizen of Ukraine and about passport of citizen of Ukraine for departure abroad", Articles 42, 51 of the Principles of legal system of Ukraine about the health care, Decree of MH of Ukraine from 3 February 2011 yr No 60 «About improvement of medical care to persons, who need the gender change (correction)» and Decree of Ministry of Health of Ukraine from October 5, $2016 \mathrm{yr}$ No 1041 «About installation of medico-biological and social-psychological indications for change (correction) of gender and implementation of legislation acts for primary accounting documentation form and instruction about its filling», (further - Decree of MH of Ukraine from October 5 , 2016 yr No 1041)

Results. Still remain an actual the issue of legislative support of correction (changes) of gender determination in Ukraine and lacks uniform principle of following for a certain algorithm in the physician-surgeon actions during treatment of surgical patients, but in accordance to the Order of MH of Ukraine from October $52016 \mathrm{yr}$ No 1041 a procedure for the permission obtaining for the gender correction procedure had become somewhat simplified. But the provisions of this Order till nowadays cause the discussion and may have legislative consequences for physician-surgeon, who executes official functions.

Conclusion. Activity of MH of Ukraine, directed on adaptation to the world standards of legislative norms, concerning the changes (correction) of gender, needs the state support, implementation of certain programs, and further legislation initiative with the objective to establish the mentioned Orders on the state level, concerning the persons, the gender of whom is undetermined.

Keywords: surgery; normative-legislative base; transsexual; the gender politics.
\end{abstract}

У результаті швидкого темпу розвитку суспільного устрою виникає потреба перегляду не лише сталих понять морально-етичних цінностей, а й багатьох догматичних тверджень, одним із яких є визначення статі особи. В Україні ще зовсім недавно бажання особи здійснити корекцію статевої належності розглядали як психічну аномалію, що потребувала примусового лікування. Наявність декількох різновидів статі з медичної точки зору, зокрема генетичної, гормональної, соматичної, психосексуальної, має відповідати лише одному соціальному (паспортно- 
му) різновиду - чоловіча чи жіноча стать, який і має бути зафіксований у документі, що ідентифікує особу, у відповідності до Постанови Верховної Ради України «Про затвердження положень про паспорт громадянина України та про паспорт громадянина України для виїзду за кордон» [1]. Необхідно зауважити, що відповідно до статті 51 Основ законодавства України про охорону здоров'я особі, якій було здійснено зміну статевої належності, видається медичне свідоцтво, на підставі якого надалі вирішується питання про відповідні зміни в ііі правовому статусі [2].

Медицині вже давно відомі хромосомні аномалії, зокрема, синдром Тернера (45 XО) чи синдром Клайнфельтера (47 XXY; 47 XYY; 48 XXXY; 48 XYYY; 48 XXYY; 49 XXXXY; 49 XXXYY), які впливають на визначення статі. Однак наявність набору хромосом ХХ чи ХY не є підставою для визначення соціальної статі людини. Саме тому поняття гермафродитизм, трансфестизм, трансгендерність (гендерна дисфорія), транссексуальність потребують не лише медичної, а й правової регламентації, особливо якщо це вливає на визначення соціальної (паспортної) статі людини.

Трансфестизм (кросдресерність) - форма порушення гендерної ідентичності, що проявляється в прагненні грати роль протилежної статі, носити одяг протилежної статі, хоча це не супроводжується повним усвідомленням себе особою іншої статті, відповідно до МКХ-10 віднесений до класу V «Психічні та поведінкові розлади» (FO0 F99), а саме до розладів статевої ідентифікації (код F64) та розладів сексуальної переваги (код F65), і не потребує корекції морфологічної статі [3].

Натомість трансгендерність (цим збірним терміном позначають явища розбіжності соціальної і біологічної статті) потребує хірургічної корекції статі для забезпечення повноцінної психосоціальної адаптації особи. Зокрема, гендерна дисфорія (розлад гендерної ідентичності) є характерною для трансгендерного стану, коли людина не може повністю визнати свій гендерний статус чоловіка чи жінки.

У проекті МКХ-11 трансгендерність не віднесено до розладів статевої ідентифікації, а гендерну дисфорію визначено як gender incongruence.

Транссексуальність (код F64.0) - форма гендерної дисфорії, коли індивідуум повністю не сприймає свій гендерний статус і бажає його зміни, включаючи відповідну хірургічну операцію та зміну паспортної статі. Транссексуальність не передбачає сексуального потягу до конкретно визначеної статі. Тому можливі гомо-, гетеро-, бісексуальність та сексуальний потяг до трансгендера.

Гендерною неконформністю вважають у першу чергу зовнішні прояви гендерного самовідчуття людини. Вона може виникати у дітей, коли вони висловлюють бажання носити одяг протилежної статі, відмовляються від діяльності, що є типовою для їх статі, заводять друзів протилежної статі. Гендерна неконформність зберігається у 6 23\% дорослих чоловіків та у 17 - 27\% дорослих жінок [4].

Наразі існують і зовсім нові поняття, як то агендер людина, яка не відносить себе ані до чоловічої, ані до жіночої статі. Фізіологічно агендери можуть бути будь-якої статі і зовнішності, хоча деякі з них прагнуть мати вигляд андрогінів - осіб, які визначають свою гендерну ідентич- ність як таку, що поєднує у собі якості жіночого і чоловічого гендерів, щодо них можна застосовувати поняття третьої статі. Бігендери - люди 3 «плаваючою» гендерною ідентичністю, які виконують у суспільстві то традиційно «жіночу», то традиційно «чоловічу» роль залежно від настрою, обставин та оточення [4].

Проведені у 1988 р. дослідження у восьми країнах показали, що на 11900 - 45000 чоловіків припадає один MtF-транссексуал (потяг до жіночої статі), а на 30400 200000 жінок - один FtM-транссексуал (потяг до чоловічої статі) [4].

Мета дослідження. Аналіз сучасного стану правового забезпечення хірургічної корекції статевої належності в Україні.

\section{Матеріали і методи дослідження}

Проаналізовано Постанову Верховної Ради України «Про затвердження положень про паспорт громадянина України та про паспорт громадянина України для виїзду за кордон», статті 42, 51 Основ законодавства України про охорону здоров'я, Наказ Міністерства охорони здоров'я України від 3 лютого 2011 р. № 60 «Про удосконалення надання медичної допомоги особам, які потребують зміни (корекціі) статевої належності» та Наказ Міністерства охорони здоров'я України від 5 жовтня 2016 р. №1041 «Про встановлення медико-біологічних та соціальнопсихологічних показань для зміни (корекціi) статевої належності та затвердження форми первинної облікової документації й інструкції щодо ії заповнення» (далі - Наказ МО3 України від 5 жовтня 2016 р. № 1041).

\section{Результати}

У травні 2018 р. уряд Німеччини схвалив законопроект, за яким органи реєстрації актів цивільного стану невдовзі зможуть офіційно фіксувати не лише чоловічу чи жіночу, а й третю стать у свідоцтвах про народження. Відповідно до даного документа з'явиться нова графа «нша стать». Обрати іншу стать зможуть агендери (інтерсексуали), а 3 часом також люди, що не погоджуються зі статтю, яка була визначена для них під час народження.

За світовою лікарською практикою у разі корекції статі, правила якої регламентовані та затверджені «The World Professional Association of Transgender Health, WPATH, 2011», діагноз «гендерна дисфорія» у підлітків встановлюють психіатри відповідно до критеріїв розладів гендерної ідентичності (DSM-IV-TR3), ендокринологи призначають гормональну терапію підлітку після 16 років, плавно підвищуючи кількість гормонів, а у дорослих визначають допустимість гормонотерапії та вибір їі схеми після висновку психіатра. Хірургічна зміна статі можлива після 18 років, якщо пацієнт добре реагує на гормональну терапію, та не раніше як через рік у разі досягнення стабільних результатів гормональної терапії.

Медичні втручання у підлітків поділяють на три категоріiі.

Перша. Повністю оборотні втручання, які включають гормональну терапію для припинення секреції естрогену або тестостерону, що уможливлює відстрочити настання тілесних пубертатних змін. Альтернативними варіан- 
тами терапії є прийом прогестинів (найчастіше ДепоПровера) або інших препаратів (верошпірон), які послаблюють дію андрогенів, що виділяються яєчками (якщо підліток не приймає аналоги гонадоліберину). Для припинення менструації можуть застосовуватися пероральні контрацептиви (або Депо-Провера).

Друга. Частково оборотні втручання, які включають гормональну терапію з маскулінізації або фемінізації тіла. Деякі зміни, викликані гормонами, можуть потребувати пластичних операцій для досягнення результату (наприклад, гінекомастія, викликана естрогенами), в той час як інші зміни є незворотні (наприклад, зниження голосу, викликане тестостероном).

Третя. Необоротні втручання (хірургічні операціi), спрямовані на зміну тіла, виконувати їх рекомендують поетапно, переходити до наступного етапу не варто, поки не пройде достатньо часу для того, щоб підліток і його батьки повністю адаптувалися до змін, що відбулися.

Раніше в Україні корекція (зміна) статевої належності була регламентована Наказом Міністерства охорони здоров’я України від 3 лютого 2011 року №60 «Про удосконалення надання медичної допомоги особам, які потребують зміни (корекції) статевої належності», нормою якого для подальшої корекції статі та зміни документів передбачено обов'язкову стерилізацію трансгендерів [5]. Крім того, особам, які планують корекцію статі, необхідно було виконати певний обсяг заходів та отримати дозвіл від Комісії з питань зміни (корекціі) статевої належності при МОЗ України.

Тривалі дискусії щодо цих правових аспектів змусили МОЗ України розробити та видати Наказ від 5 жовтня 2016 року №1041, яким встановлено медико-біологічні та соціально-психологічні показання для зміни (корекціi) статевої належності та затверджено Форму первинної облікової документації №066-3/о «Медичне свідоцтво про зміну (корекцію) статевої належності» та інструкцію щодо ії заповнення [6].

\section{Обговорення}

Відповідно до нормативно-правової бази України медико-біологічними показаннями для зміни (корекціi) статевої належності є психічні і поведінкові розлади (транссексуалізм) за МКХ - 10; соціально-психологічними дискомфорт або дистрес, обумовлені розбіжністю між статевою ідентичністю індивідуума і статтю, встановленою йому при народженні, і пов'язаними з цим гендерною роллю та/або первинними і вторинними статевими ознаками.

Правовим критерієм для виконання хірургічної корекції статевої належності є повноліття. Особа, яка бажає змінити статеву належність, має звернутися в поліклініку до терапевта (сімейного лікаря), щоб отримати направлення до лікаря-сексолога (сексопатолога, психіатра) для встановлення діагнозу «транссексуалізм» та постановки на облік, який передбачає медичний нагляд не менш як 2 роки. Паралельно необхідно звернутися до ендокринолога для проведення гормональної терапіі, яка має безперервно тривати 12 (18) місяців. Також особа повинна 12 місяців жити в гендерній ролі, яка збігається з гендер- ною ідентичністю. Натомість законодавець не визначає, хто саме і в який спосіб має підтвердити чи спростувати проживання особи в певній гендерній ролі.

Критерії придатності для певних видів хірургічного втручання такі.

Для MtF-пацієнтів (зміна на жіночу стать): 18 місяців гормональної терапії до операції зі збільшення грудей, щоб максимізувати ріст грудей та отримати кращі естетичні результати. Також можлива пенектомія, орхіектомія, емаскуляція, вагінопластика, кліторпластика та/або лабіопластика.

Для FtM-пацієнтів (зміна на чоловічу стать): реконструкція грудей (мастектомія). Для гістеректомії та/або видалення придатків матки потрібна наявність у пацієнта виписки із медичної карти амбулаторного (стаціонарного) хворого за формою 027/о, якою підтверджується наявність діагнозу, пов'язаного із гендерною дисфорією. Також можлива вагіноектомія, уретропластика, фалопластика, метоідопластика (неофалос з клітора), протезування яєчок та/або скротопластика (створення калитки).

Відповідно до Медичного свідоцтва про зміну (корекцію) статевої належності, яке видає лікувально-консультативна комісія Центру первинної медико-санітарної допомоги, у пацієнта мають бути наявні медико-біологічні і соціально-психологічні показання для зміни (корекціi) статевої належності. В п. 2 даного свідоцтва $€$ такий запис: «Обсяг медичного втручання в закладах охорони здоров'я щодо зміни (корекції) статевої належності включав ...». Саме поняття «медичне втручання» викликає суперечки між юристами, які захищають право особи, яка бажає змінити стать, та лікувальним закладом, який доволі часто трактує це поняття як виключно хірургічне втручання. Відповідно до ст. 42 Основ законодавства України про охорону здоров'я медичним втручанням є застосування методів діагностики, профілактики або лікування, пов'язаних із впливом на організм людини [2]. Виходячи 3 цього, використання повноцінної гормональної терапії цілком достатньо для зміни статі.

Варто зазначити, що в Україні немає державної програми, покликаної допомогти особі змінити стать, a хірургічна корекція є вартісною процедурою, яку виконують переважно у приватних лікувальних закладах. Саме тому особі не обов'язково одразу фізично змінювати статеву належність.

В Україні законодавчо не регламентовано встановлення та визначення статі у разі наявності у людини аномального набору хромосом, що призводить до невідповідності психологічного профілю фенотипічним проявам. Особливо проблемним є стан, коли особа має чоловічі та жіночі статеві ознаки, обумовлені аномальними рівнями гормонів обох статей. За таких умов особа може відчувати себе агендером, а тому для неї не підходить законодавчо визначена чоловіча чи жіноча стать.

\section{Висновки}

Діяльність МОЗ України, яке розпочало процес приведення правової регламентації зміни (корекції) статевої належності в Україні до світових стандартів, потребує не лише державної підтримки та запровадження відповідних 
програм, а й подальшої законодавчої ініціативи з метою закріплення даних положень на державному рівні стосовно до осіб, стать яких є невизначеною.

\section{References}

1. Postanova Verkhovnoi Rady «Pro zatverdzhennia polozhen pro pasport hromadianyna Ukrainy ta pro pasport hromadianyna Ukrainy dlia vyizdu za kordon». No 5294-VI redaktsiia vid 18.10.2012 r. [Internet]. Available from: http://zakon.rada.gov.ua/laws/show/2503-12. [In Ukrainian].

2. Zakon Ukrainy «Osnovy zakonodavstva Ukrainy pro okhoronu zdorovia» vid 19.11.1992 r. (Vidomosti Verkhovnoi Rady Ukrainy (VVR), 1993, No 4, st. 19) [Internet]. Available from: https://xn - 80aagahqwyibe8an.com/ukrajiny-zakony/zakon-ukrajini-osnovi-zakonodavstvaukrajini.html [In Ukrainian].
3. Mizhnarodna klasyfikatsiia khvorob MKKh-10 [Internet]. Available from:http://www.wikiwand.com/uk. [In Ukrainian].

4. Nanda Serena. Gender Diversity: Cross cultural Variations, Second Edition. Waveland Press, Inc.: USA; 2014. 147 p.

5. Nakaz MOZ Ukrainy vid 03 liutoho 2011 roku № 60 «Pro udoskonalennia nadannia medychnoi dopomohy osobam, yaki potrebuiut zminy (korektsii) statevoi nalezhnosti». [Internet]. Available from: http://zakon. rada.gov.ua/laws/show/z0239-11.[In Ukrainian]

6. Nakaz MOZ Ukrainy vid 05 zhovtnia 2016 roku № 1041 «Pro vstanovlennia medyko-biolohichnykh ta sotsialno-psykholohichnykh pokazan dlia zminy (korektsii) statevoi nalezhnosti ta zatverdzhennia formy pervynnoi oblikovoi dokumentatsii y instruktsii shchodo yii zapovnennia». [Internet]. Available from: http://search.ligazakon.ua/__doc2.nsf/link1/ RE29719Z.html. [In Ukrainian]. 